\title{
РЕАЯІЗАЦІЯ СИСТЕМНО-СИНЕРГЕТИЧНОГО ПІДХОДУ ДО НАВЧАННЯ УКРАЇНСЬКОЇ МОВИ ЗА ПРОФЕСІЙНИМ СПРЯМУВАННЯМ
}

Стаття присвячена вивченню синергетичних проявів у процесі еволюційних змін структури, змісту та організації навчання курсу «Украӥнська мова за професійним спрямуванням» у педагогічних закладах вищої освіти. Завданням дослідження є висвітлення основних напрямів реалізації синергетичного підходу в межах навчальної дисциилхни. На основі позицій синергетики встановлено, щзо аналізований курс є диналічною, відкритою, нелінійною системою, яка охоплюе певну кількість підсистем: змістову, методичну, парадигматичну, інструментальну, лінгвістичну, - що зазнатоть змін під упливом суспільних і політичних чинників.

До зовнішнього кола синергетики украӥнської мови за професійним спрямуванням віднесено взаємодію елементів системи керування процесом навчання. Внутрішні синергетичні кола дисиипліни вибудовуються із мовної системи, системи позамовних чинників і системи професійного мовлення. Сучасне розуміння мови як складної, динамічної, саморегульованої системи можливе на основі опанування ї̈ підсистем $i$ само по собі є прикладом аналізованого підходу до мовної освіти. Авторка наголошуе на синергетичному баченні механізмів виникнення мовленневого твору у фаховому контексті як важливому чиннику підвищення комунікативної компетентності студентів.

Описано шляхи досягнення ефекту «надлишку освіти» під час виконання самостійної роботи до курсу «Українська мова за професійним спрямуванням». Професійний комунікативний дискурс, крім хінгвістичної основи, вимагае залучення інформації, отриманої з інших дисциилін. Синергетика дає можливість об'єднання різнонаукових аспектів у єдину систему пізнання. Окреслено мотиваційний вплив синергетики у межах курсу. Результати проведеного дослідження використано для побудови моделі застосування синергетичного підходу до навчання української мови за професійним спрямуванням.

Ключові слова: педагогічна освіта, синергетика, комунікативний дискурс, мовна система, освітня парадигма, професійне мовлення, екстрахінгвістичні засоби, компетентність.

Постановка проблеми. Метою педагогічної освіти є підготовка фахівця, готового до швидких освітніх трансформацій, зорієнтованого на безперервну самоосвіту, самоорганізацію, постійне вдосконалення своїх компетентностей відповідно до глобальних та національних викдиків, не обмеженого установками чи стереотипами. У таких динамічних умовах науковці почали звертати увагу на синергетику як оптимадьний підхід до керування педагогічними процесами. Нагодошуючи на його міждисциплінарності, дослідники формулюють призначення синергетичного підходу в освіті: «виявити закономірності становлення і самоорганізації складних систем, незалежно від конкретної природи складових їх компонентів» [12, с. 263].

Сучасний науковий простір ілюструє процес адаптації синергетики до сфери педагогічних, екологічних, економічних та інших знань на основі розробок класичних дисциплін (фізики, хімії, математики), у межах яких виникла ця наукова модель пізнання. Спираючись на основоположне трактування синергетики німецького фізика Г. Хакена не тільки як науки про самоорганізацію, але й теорію «спільної дії багатьох підсистем, у результаті якої на макроскопічному рівні виникає нова структура

*(C) Гуменюк I. М.

us 121 
і відповідне функціонування» [18, с. 7], дослідники підкреслюють наявність у педагогічному процесі таких взаємодій, які вивчаються синергетикою [4, с. 76]. Відповідно до основних синергетичних принципів відносять «нелінійність, нестійкість, незамкнутість, динамічну ієрархічність, спостережуваність» [9, с. 66].

Аналіз досліджень. Поняття системно-синергетичного підходу в українській педагогіці вперше вжито професором М. Таланчуком у контексті створеної ним нової методологічної моделі розвитку [17] й отримало подальшу деталізацію у різних наукових сферах, найбільше - в працях економічного та екологічного напрямків. Педагогічне застосування системно-синергетичного підходу обгрунтовує С. Вітвицька, наголошуючи на взаємозв' язку, цілісності та фундаментальності знань у XXI столітті [2].

Позиція синергетики грунтується на тому, що будь-який об'єкт іiі вивчення є системним, тобто цілісним явищем, компоненти якого знаходяться у постійній взаємодії. У цьому контексті українська мова за професійним спрямуванням (УМзаПС) як навчальна дисципліна є динамічною, відкритою, нелінійною системою, що охоплює певну кількість підсистем: змістову, методичну, парадигматичну, інструментадьну, дінгвістичну та ін. Жодна з них не є замкнутою, стабільною чи постійно стійкою, як і сам курс. Вони зазнають змін під упливом суспільних і політичних чинників, що стає основним важелем управління синергетичною системою. Ю. Козловський зазначає: «Суттєва особливість синергетичних систем полягає в тому, що ними можна управляти, змінюючи діючі на них зовнішні фактори. Причому інколи незначна зміна останніх може привести до кардинальної зміни системи загалом» [9, с. 67]. Таке явище чітко спостерігається в процесі еволюції змісту дисципліни у зв'язку із соціальнополітичними трансформаціями [5]: 1) створення предметного курсу відповідно до прийнятого 1989 року Закону про мови в УРСР; 2) модифікації найменування і змістового спрямування УМзаПС від дінгвістичного, документознавчого до професійно-комунікативного; 3) компресія змісту під впливом зменшення годин на вивчення дисципліни; 4) погдиблення науково-методичних досліджень у зв'язку 3 прийняттям Постанови Кабінету Міністрів України № 998 від 08.09.1997 «Про затвердження комплексних заходів щодо всебічного розвитку і функціонування української мови» [14]; 5) затвердження УМзаПС як нормативної дисципліни у 2009 році та створення типової програми з новими змістовими модулями [15]; 6) зміна статусу дисципліни після прийняття Закону «Про вищу освіту» № 1556-VII від 1 дипня 2014 року [13].

Мета статті - визначення напрямів реалізації положень синергетики у процесі навчання української мови за професійним спрямуванням.

Виклад основного матеріалу. Еволюція змісту курсу закономірно спричинила зміни у формулюваннях мети навчання УМзаПС, завдань, очікуваних результатів, тобто зазнала трансформації парадигматична підсистема. А це, в свою чергу, вплинуло на добір підходів, технодогій, методів, прийомів, форм і засобів навчання. Такий взаємовплив відображає зовнішне коло синергетики аналізованої дисципліни, 3 прямим виходом у соціум.

Одне із внутрішніх синергетичних кіл УМзаПС складає мова як об'єкт вивчення. Жодна 3 відомих концепцій навчання дисципліни не заперечує дінгвістичного компонента в їі структурі. Без необхідного рівня мовної компетентності формування професійно-комунікативних умінь стає надто важким завданням. Мова як система систем знаходиться в центрі дінгвістичних досліджень, об'єднуючи 4 підсистеми, або рівні: фонологічний, морфологічний, лексико-семантичний, синтаксичний [8, с. 15]. Ці підсистеми взаємопов'язані, на їх полях перетину виникають проміжні підсистеми: морфонологічна, словотвірна і фразеологічна [так само, с. 16]. Взаємодіючи між собою, підсистеми спричиняють зміни, розвиток мовної системи, демонструючи синергетичні ознаки. Сучасні лінгвісти переконані, що «мову в рамках нової постнекласичної наукової парадигми слід розглядати як відкриту, складну, нелінійну систему людського мислення

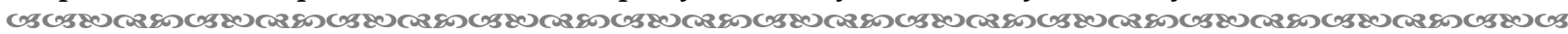
122 
і спілкування, пізнання світу і конструювання його моделі» [11, с. 120]. Таке розуміння спричинило появу нового напрямку у філології - дінгвістичної синергетики, концептуальну основу якої складають філософія, дінгвістика та синергетика [7, с. 69]. 3 цієї позиції у контексті УМзаПС вивчаються питання диференціації понять «мова» i «мовлення», української національної та української літературної мов, інтерпретації основних функцій мови, визначення мови професійного спілкування, стабільність і динаміка мовних норм, історія формування української термінології та ін. Таким чином, сучасне розуміння мови як складної, динамічної, саморегульованої системи мождиве на основі опанування іï підсистем і само по собі є прикладом синергетичного підходу до мовної освіти.

Оскільки професійно-комунікативна діяльність охоплює і писемну, й усну форми мови, а саме створення усних висловлювань викликає найбільше труднощів під час навчання, синергетичне бачення механізмів виникнення мовленнєвого твору у фаховому контексті стає важливим чинником підвищення комунікативної компетентності студентів.

Загальне уявлення цього процесу знаходимо в працях $А$. Бронник: для появи осмисленого повідомлення потрібен інтелект, що базується на когнітивній системі, складниками якої є концептуальна і мовна системи. Ці складові перебувають у стані рівноваги до того моменту, поки на інтелект не вплине певне джерело інформації (зовнішне або внутрішне), що вимагае вербальної реакції [1, с. 35]. Однак вербальна реакція потребуе залучення усіх підсистем мовної системи, супроводжується використанням екстралінгвістичних засобів, а у професійному контексті вимагає ще й вододіння відповідною терміносистемою та адекватного розуміння ситуації. Отже, окреслюється ще одне внутрішнє синергетичне коло УМзаПС - усне професійне мовлення. А. Малевич та М. Дзюба, розглядаючи синергетичний підхід до викладання української мови, наголошують на «варіативності мовних одиниць різних рівнів, яка є і обов'язковою передумовою успішного функціонування мовної системи, і наслідком мовленнєвої діяльності, зорієнтованої на задоволення змінюваних потреб комунікації» [10, с. 270]. У такому контексті розглядаємо вибір стидістичних засобів упроцесі побудови висловлювання, використання екстралінгвістичних елементів, аспекти культури фахової мови, термінологічну синонімію, переклад і редагування наукового тексту тощо.

Системно-синергетичний підхід до керування процесом навчання УМзаПС грунтуеться на сучасних дослідженнях синергетичних закономірностей освітньої діяльності, забезпечуючи водночас цілісність цього процесу, сприяючи розумінню принципів самоорганізації системи. Така методологія дозволяе застосувати не тільки аналіз компонентів системи, але й складний синтез усіх підсистем у єдину нову цілісність, у результаті чого з'являеться нове складніше утворення. Зокрема, вивчення мови як системи ще не є запорукою вміння користуватися ії компонентами, вдало й доречно поєднуючи їх у мовленнєвому потоці. Саме синкретичне бачення закономірностей взаємодії мовних засобів, їх функцій у різноманітних контекстах створюе підгрунтя для самоорганізації отриманих знань у функціонадьному, нелінійному просторі. Професійний комунікативний дискурс, крім дінгвістичної основи, вимагає залучення інформації, отриманої з інших дисциплін. Синергетика дає мождивість об'єднання різнонаукових аспектів у єдину систему пізнання. Наголошуючи на тому, що в сучасному інформаційному суспільстві спеціалізована інформація дуже швидко знецінюється, науковці наподягають на необхідності синтетичного знання, «отриманого на грунті міждисциплінарних зв'язків та новітніх наукових напрямів, що забезпечать актуалізацію цього процесу» [3, с. 139].

Очевидно, що навчання професійному мовленню не дорівнюе набуттю загальних мовних компетентностей. Вони повинні вдосконалюватися у дискурсі майбутньої фахової діяльності, переплітатися з елементами професійної компетентності вчителя.

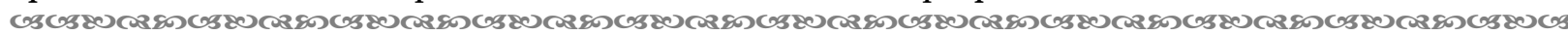


Така нелінійність навчання УМзаПС досягається шияхом використання мудьтимедійних навчальних ресурсів, зокрема, для вирішення ситуативно-комунікативних завдань («Запізнення на роботу», «Співбесіда 3 працедавцем», «Конфлікт між учнями», «У кабінеті директора» та ін.), впізнавання і сприймання фахової термінології у мовному потоці (професійні діалоги, наукові публікації, інтерв'ю на педагогічну тему тощо), встановлення стильової відповідності мовлення ситуації, спостереження за дією основних законів спілкування, «читання» невербальних сигналів, синхронне редагування усних висловлювань та ін.

У результаті інтерактивної взаємодії на заняттях студенти повинні усвідомити різноманітність і непередбачуваність професійно-комунікативних ситуацій, вдовити загальні закономірності ведення професійного діалогу, сформувати розуміння того, що після завершення формальної освіти потреба у вдосконаленні професійного мовлення не зменшується. Навпаки, кожна реальна ситуація підштовхуе до адекватної самооцінки, виявлення недоліків і налаштування на безперервну самоосвіту.

Описаний синергетичний ефект у навчальному процесі отримав назву «надлишку освіти», що передбачає таку організацію викладання, за якої співпраця студентів дає можливість досягнути навчального результату, якісно вищого за діяльність кожного окремого студента [19, с. 92]. Іиюстрація синергетичного навчадьного надлишку здійснена І. Грабар та Т. Енглер через формулу $2+2=5$ ', що показуе, як взаємодія складових виводить процеси в системі на більш якісний рівень, а сама система у зворотньому порядку покращуе кожну зі складових [там само].

Реалізація синергетичного підходу до навчання грунтується не на відтворенні інформації, вона орієнтована в напрямку овододіння методологією побудови системи знань, способами ії оновлення, критичного відбору та творчого використання матеріаду. Тобто розкриття можливостей, методів і шляхів самонавчання лежить в основі синергетичної концепції в педагогіці. 3 огляду на це вибудовується система самостійної роботи студентів 3 курсу «УМзаПС»: як сукупність тематичних пошукових завдань, об'єднаних професійним контекстом, результатом виконання яких є продукт одноосібної або командної діяльності студентів, що презентується аудиторно чи онлайн (за дистанційної форми навчання). «Навчальним надлишком» у цьому випадку стає набута чи вдосконалена підприємницька компетентність (часова, інформаційна, прагматична) [6], навички роботи в команді, вміння належно оформити й презентувати інформацію. Такими продуктами самостійної студентської роботи в контексті УМзаПС можуть бути інформаційний проєкт, словних термінів дисципліни 3 цитованим контекстом, збірник фахових текстів, індивідуальна папка зі зразками ділової документації, стилістичне оформлення текстів, організація та проведення дискусії, мозкового штурму, педагогічної наради, конференції тощо.

Серед детермінант синергетичного підходу до навчання дослідники виділяють також його мотиваційний аспект: «синергетичний підхід... полягає в стимудюючому впливові на суб'єкт навчальної діяльності 3 метою його саморозкриття й самовдосконалення в процесі співробітництва 3 іншими дюдьми й із самим собою» $[16$, с. 94]. Системна організація знань студентів, робота в групах, використання усіх доступних джерел інформації та способів ії презентування, творчий пошук, бачення професійного зв' язку та реальних результатів своєї діяльності - втілення мотиваційного впливу синергетики у межах дисципліни «УМзаПС».

Візуалізацію моделі застосування синергетичного підходу до навчання УМзаПС здійснено на рис. 1.

Висновки. Синергетичний погляд на процес навчання УМзаПС підкреслюе відкритість, взаємозв' язок і взаємодію усіх внутрішніх систем та підсистем, у результаті якої змінюеться і досягає рівноваги на певний період система навчання дисципліни, що може бути порушена наступними впливами зовні чи зсередини. 


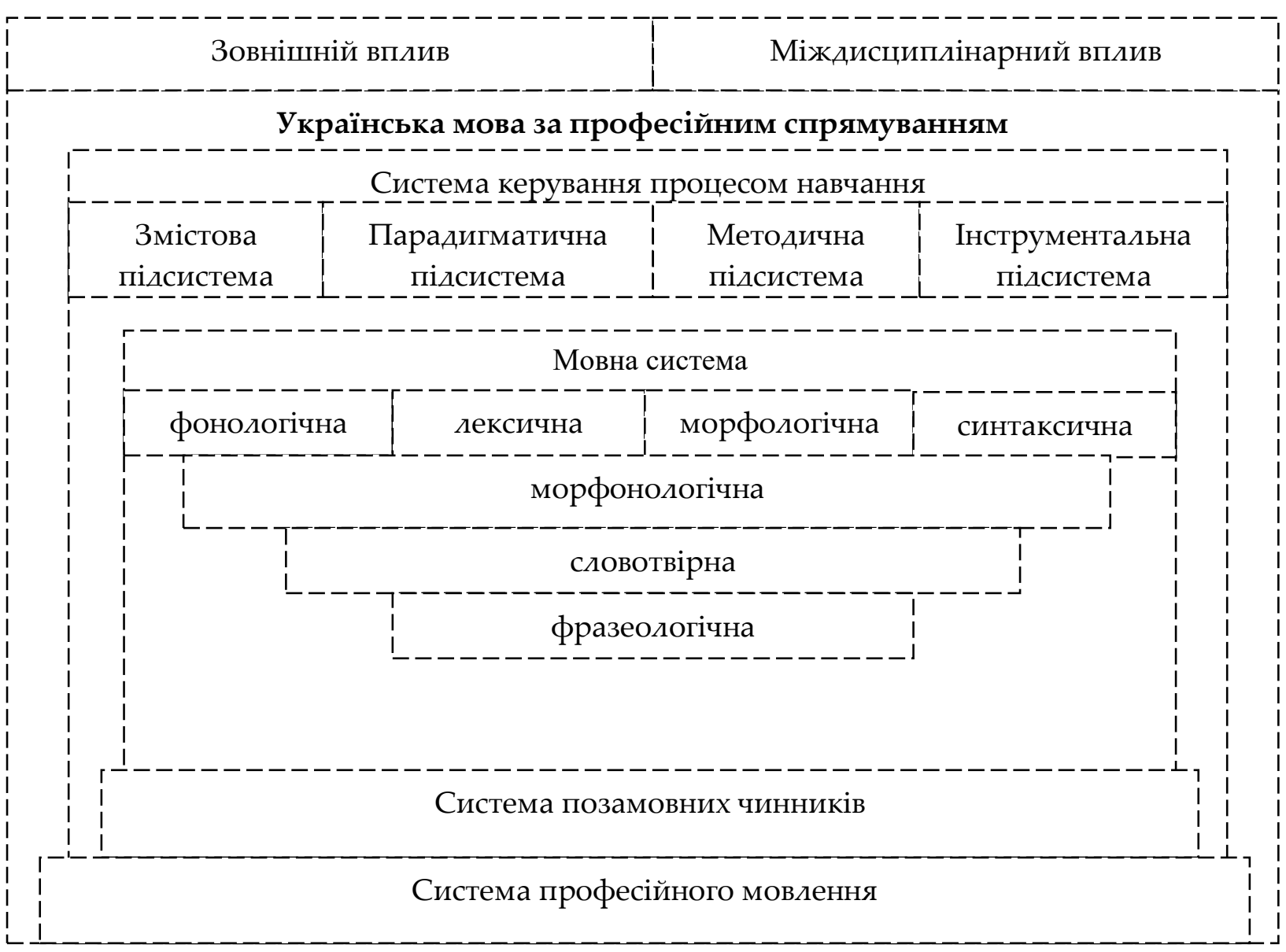

Рис. 1. Синергетичний підхід до процесу навчання УМзаПС

Джерело: розроблено автором.

Отже, до напрямів реалізації положень синергетики в процесі навчання УМзаПС належать: 1) синергетичність побудови змісту дисципліни, що базується на його відкритості, сприйнятливості до суспільних запитів і глобальних тенденцій, професійній адаптації; 2) синергетичність застосовуваних освітніх парадигм: поглядів, ідей, напрямів та ін.; 3) синергетичність методичної системи, що орієнтуе на інноваційність, інтерактивність, творчість, міждисциплінарність; 4) синергетичність навчальних засобів та інструментів, система яких активно реагуе на технологічні інновації; 5) синергетичність організації міжсуб'єктної комунікації, що виявляеться в самокерованості цього процесу, використанні інноваційних форм і дослідницьких елементів; 6) розкриття синергетичності мовної та позамовної систем для формування професійної комунікативної компетентності.

Перспективним для подальших наукових досліджень вбачаємо вивчення процесу реалізації інших концептуальних підходів до мовної освіти в контексті УМзаПС.

\section{Список використаних джерел:}

1. Бронник Л. В. Когнитивная дингвосинергетика - новый этап в науке о языке и мышлении. Вестник Адыгейского гос. ун-та. Серия «филология и искусствоведение». Майкоп: АГУ, 2008. Вып. 10. С. 34-36.

2. Вітвицька С. С. Системно-синергетичний підхід до педагогічної підготовки майбутніх магістрів освіти. Професійна педагогічна освіта: системні дослідження: монографія. Житомир: Вид-во ЖДУ ім. І. Франка, 2015. С. 92-108.

3. Вознюк О. Загальнонаукові засади педагогічної синергетики. Вісник Житомирського державного університету імені Івана Франка. Вип. 37. С. 139-143. 
4. Гончаренко С. У. Педагогічні дослідження: Методологічні поради молодим науковцям. К., Вінниця: ДОВ «Вінниця», 2008. 278 с.

5. Гуменюк I. М. Ретроспективний аналіз змісту навчання української мови за професійним спрямуванням. Гірська школа Украӥнських Карпат. 2020. № 22. С. 60-66.

6. Гуменюк I. M. Формування підприємницької компетентності майбутніх фахівців педагогічного профілю. Педагогічна освіта: теорія і практика: збірник наукових праць. 2019. Вип. 26. Ч. 1. С. 52-57.

7. Домброван Т. И. Синергетическая модель развития ангдийского языка: дисс. ... д-ра филол. наук: 10.02.04. Одесса, 2013. 466 с.

8. Караман С. О. та ін. Сучасна українська літературна мова. Київ: Дітера $Л \mathrm{~T} Д, 2011.560$ с.

9. Коздовський Ю. Синергетичний підхід як методологічна основа моделювання наукової діяльності вищого навчального закладу. Молодь і ринок. 2012. № 4 (87). С. 65-70.

10. Малевич А., Дзюба М. Синергетичний підхід до викладання української мови в технічних ВНЗ. Вісник Аьвівського університету. Серія: Філологія. 2010. Вип. 50. С. 268-273.

11. Некипелова И. М. Языковая система как объект исследования постнеклассической науки. Филологические науки. Вопросы теории и практики. Тамбов: Грамота, 2013. № 1 (19). С. 116-121.

12. Овчинникова М. В. Синергетичний підхід як методологічна основа дослідження системи підготовки майбутніх учителів математики до науково-дослідницької діяльності. Проблеми сучасної педагогічної освіти. Педагогіка і психологія. 2013. Вип. 39 (2). С. 263-271.

13. Про вищу освіту. Закон України № 1556-VII від 1 липня 2014 року. Перша редакція. URL: https://zakon.rada.gov.ua/rada/show/ru/1556-18/ed20140701

14. Про затвердження компдексних заходів щодо всебічного розвитку i функціонування української мови. Постанова Кабінету Міністрів України від 8 вересня 1997 року № 998. Київ. URL: https://zakon.rada.gov.ua/ laws/show/998-97-\%D0\%BF

15. Про організацію вивчення гуманітарних дисциплін за вільним вибором студента. Наказ МОН України № 642 від 09.07.2009. URL: https://osvita.ua/legislation/Vishya osvita/6122/

16. Рідкодубська А. А. Синергетичний підхід у підготовці до професійної мобільності майбутніх фахівців. Фізико-математична освіта: науковий журнал. 2017. Випуск 1 (11). С. 93-96.

17. Таланчук Н. М. 100 новых идей в педагогике, связанных с открытием фундаментальных законов системного синергетизма: Эвристический тезаурус. Казань: ИССО РАО, 1993. 105 с.

18. Хакен Г. Синергетика. Москва: МИР, 1980. 405 с.

19. Grabar I., Engler T. Synergetic approach to teaching foreign languages at undergraduate technical institutions. Advances in Business-Related Scientific Research Journal (ABSRJ). 2011. Vol. 2. No. 1. P. 89-99.

\section{References:}

1. Bronnik, L. (2008). Kognitivnaia lingvosinergetika - novyi etap v nauke o iazyke i myshlenii [Cognitive linguosynergetics is a new stage in the science of language and thinking]. Vestnik Adygeiskogo gos. un-ta. Seriia «filologiia i iskusstvovedenie», 10, 34-36 [in Russian].

2. Vitvytska, S. (2015). Systemno-synerhetychnyi pidkhid do pedahohichnoi pidhotovky maibutnikh mahistriv osvity [The systemic and synergetic approach to pedagogical preparation of future masters of education]. In Profesiina pedahohichna osvita: systemni doslidzhennia [Professional pedagogical education: systematic research] (pp. 92-108). Zhytomyr: Vyd-vo ZhDU im. I. Franka [in Ukrainian].

3. Vozniuk, O. (2008). Zahalnonaukovi zasady pedahohichnoi synerhetyky [The scientific principles of pedagogical synergetics]. Visnyk Zhytomyrskoho derzhavnoho universytetu imeni Ivana Franka, 37, 139-143 [in Ukrainian].

4. Honcharenko, S. (2008). Pedahohichni doslidzhennia: metodolohichni porady molodym naukovtsiam [Pedagogical research: methodological advice for young scientists]. Kyiv, Vinnytsia: DOV «Vinnytsia» [in Ukrainian].

5. Humeniuk, I. (2020). Retrospektyvnyi analiz zmistu navchannia ukrainskoi movy za profesiinym spriamuvanniam [Retrospective analysis of the content of teaching Ukrainian Language for Professional Purposes]. Hirska shkola Ukrainskykh Karpat, 22, 60-66 [in Ukrainian].

6. Humeniuk, I. (2019). Formuvannia pidpryiemnytskoi kompetentnosti maibutnikh fakhivtsiv pedahohichnoho profiliu [Formation of future pedagogical specialists' entrepreneurial competence]. Pedahohichna osvita: teoriia i praktyka, 26, 1, 52-57 [in Ukrainian].

7. Dombrovan, T. (2013). Sinergeticheskaia model razvitiia angliiskogo iazyka [A synergetic model of development of the English language]. (Doctor's thesis). Odesa [in Russian]. 
8. Karaman, S. O. (2011). Suchasna ukrainska literaturna mova [Modern Ukrainian literary language]. Kyiv: Litera LTD [in Ukrainian].

9. Kozlovskyi, Yu. (2012). Synerhetychnyi pidkhid yak metodolohichna osnova modeliuvannia naukovoi diialnosti vyshchoho navchalnoho zakladu [Synergetic approach as a methodological basis for modelling the scientific activity of a higher education institution]. Molod i rynok, 4 (87), 65-70 [in Ukrainian].

10. Malevych, L., \& Dziuba, M. (2010). Synerhetychnyi pidkhid do vykladannia ukrainskoi movy v tekhnichnykh VNZ [Sinergistical approach to teaching of Ukrainian language in higher technical education institutions]. Visnyk Lvivskoho universytetu. Seriya: Filolohiya, 50, 268-273 [in Ukrainian].

11. Nekipelova, I. (2013). Yazykovaia sistema kak obekt issledovaniia postneklassicheskoi nauki [Language system as research object of postnonclassical science]. Filologicheskie nauki. Voprosy teorii i praktiki, 1 (19), 116-121 [in Russian].

12. Ovchynnykova, M. (2013). Synerhetychnyi pidkhid yak metodolohichna osnova doslidzhennia systemy pidhotovky maibutnikh uchyteliv matematyky do naukovo-doslidnytskoi diialnosti [Synergetic approach as a methodological basis for the study of the system of preparing future teachers of mathematics for research activities]. Problemy suchasnoi pedahohichnoi osvity. Pedahohika i psykholohiia, 39 (2), 263-271 [in Ukrainian].

13. About higher education. Law of Ukraine dated July 1, 2014 No. 1556-VII. Retrieved from https://zakon.rada.gov.ua/rada/ show/ru/1556-18/ed20140701 [in Ukrainian].

14. About the approval of complex measures concerning comprehensive development and functioning of the Ukrainian language. Resolution of the Cabinet of Ministers of Ukraine dated September 8, 1997 No. 998. Retrieved from https://zakon.rada.gov.ua/laws/show/998-97-\%D0\%BF [in Ukrainian].

15. About organization of studying of humanitarian disciplines at the free choice of the student. Order of the Ministry of Education and Science of Ukraine dated July 9, 2009 No. 642. Retrieved from https://osvita.ua/legislation/Vishya osvita/6122/[in Ukrainian].

16. Ridkodubska, A. A. (2017). Synerhetychnyi pidkhid u pidhotovtsi do profesiinoi mobilnosti maibutnikh fakhivtsiv [Synergetic approach in the preparation of future specialists' professional mobility]. Fizyko-matematychna osvita, 1 (11), 93-96 [in Ukrainian].

17. Talanchuk, N. M. (1993). 100 novykh idei v pedagogike, sviazannykh s otkrytiem fundamentalnykh zakonov sistemnogo sinergetizma: Evristicheskii tezaurus [100 new ideas in pedagogy related to the discovery of the fundamental laws of systemic synergetism: a heuristic thesaurus]. Kazan: ISSO RAO [in Russian].

18. Haken, G. (1980). Sinergetika [Synergetics]. Moskva: MIR [in Russian]

19. Grabar, I., \& Engler, T. (2011). Synergetic approach to teaching foreign languages at undergraduate technical institutions. Advances in Business-Related Scientific Research Journal (ABSRJ), 2 (1), 89-99 [in English].

Humeniuk I. M., orcid.org/0000-0002-0790-6732

\section{IMPLEMENTATION OF THE SYSTEMIC AND SYNERGETIC APPROACH INTO TEACHING UKRAINIAN LANGUAGE FOR PROFESSIONAL PURPOSES}

The article focuses on the study of synergetic manifestations in the process of evolutionary changes of the structure, content and organisation of teaching of the Ukrainian Language for Professional Purposes course at pedagogical institutions of higher education. The aim of the research is elucidation of the main directions of implementation of the synergetic approach within the academic discipline. Based on the positions of synergetics, it has been determined that the analysed course is a dynamic, open and nonlinear system, which includes a certain quantity of subsystems (content, methodical, paradigmatic, instrumental, linguistic) changing under the impact of social and political factors.

The outer circle of synergetics of Ukrainian Language for Professional Purposes includes interaction between the elements of the system of management of the educational process. The inner synergetic circles of the discipline consist of the language system, the system of extralinguistic factors and the system of professional speech. The modern understanding of language as a complex, dynamic and self-regulatory system is possible due to mastering its subsystems and is an example of the analysed approach to linguistic education. The author emphasizes the synergetic vision of the mechanisms 
of emergence of a speech composition in the professional context as an important factor of increasing the communicative competence of students.

The ways of achieving the "excess of education" effect during completion of an individual work of the Ukrainian Language for Professional Purposes course have been described. Apart from the linguistic basis, the professional communicative discourse requires involvement of the information obtained from other disciplines. Synergetics provides the opportunity to merge different scientific aspects into a single system of cognition. The motivational impact of synergetics within the course has been outlined. The results of the conducted research have been used for construction of a model of application of the synergetic approach to teaching Ukrainian Language for Professional Purposes.

Ключові слова: педагогічна освіта, синергетика, комунікативний дискурс, мовна система, освітня парадигма, професійне мовлення, екстралінгвістичні засоби, компетентність.

Key words: pedagogical education, synergetics, communicative discourse, language system, educational paradigm, professional speech, extralinguistic means, competence.

Дата надходження статті: 14.01.2021 p. Рецензент: доктор педагогічних наук, професор Білавич Г. В.

У, ДК 378.147:373

DOI https://doi.org/10.37915/pa.vi48.200

Карасьова О. В. , orcid.org/0000-0001-8922-9036

\section{ТЕХНОЯОГIї Е-LЕARNING ДЯЯ ВИКЛАДАННЯ ІНОЗЕМНОї МОВИ У ФАРМАЦЕВТИЧНИХ УНІВЕРСИТЕТАХ}

У статті представлений огляд досліджень щодо застосування електронних освітніх ресурсів у фармацевтичній освіті при вивченні студентами іноземної мови. Виявлено переваги електронних освітніх технологій, зокрема технологї̈ е-learning, над традиційними методами навчання. Описано досвід використання дистанційних освітніх технологій при навчанні іноземній мові майбутніх фармацевтів в украӥнських університетах. Автором проаналізовано дослідження вчених, в яких розглядається проблема пошуку нових прийомів, способів і технологій підвищення мотивації до навчання іноземних мов майбутніх фармацевтів. Однією з ефективних технологій у статті визначено е-learning, впровадження якої сприяе вивченню іноземної мови студентів-фармацевтів. У статті дається визначення понять «педагогічна технологія» $i$ «технологія e-learning», реалізація яких сприяе забезпеченню високого рівня вивченню іноземної мови, відповідно до завдань і можливостей сучасного світу, щьо дозволить здобувачам фармацевтичної освіти пристосовуватися в умовах швидкоплинного, нестійкого навколишнього середовища, забезпечить перехід від книжкового контенту до активного за допомогою єдиного загального сховища навчальних матеріалів при наявності анахітичної системи пошуку. Доведено, що застосування технологї е-learning у процесі навчання іноземним мовам дозволяе відтворювати навчальні ситуації, допомагае доповнювати традиційні методи навчання, сприяе формуванню основних навичок іншомовного спілкування, усвідомленню можливості висловлювати дулки іншою мовою для самостійного вирішення комунікативних завдань, підвищуе бажання, інтерес студентів-фармацевтів до навчання, змушуе по-новому поглянути на їхні інтелектуальні можливості, таланти.

Зроблено висновки, ще впровадження технологї e-learning в освітній процес фармацевтичних університетів має позитивний вплив на вивчення іноземних мов здобувачами освіти.

Ключові слова: фармацевтичний ЗВО, здобувачі освіти, викладання іноземної мови, педагогічна технологія, e-learning.

*C) Карасьова O. B.

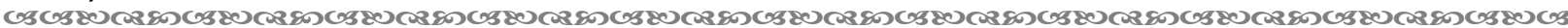
128 